\title{
Consumers' Insurance Literacy: Literature Review, Conceptual Definition, and Approach for a Measurement Instrument
}

\author{
Weedige Sampath Sanjeewa Ouyang Hongbing* \\ School of Economics, Huazhong University of Science and Technology, 1037 Luoyu Road, Hongshan District, \\ Wuhan 430074, P.R.China
}

\begin{abstract}
Improved financial literacy is the key to informed decisions, protected consumers, financial independence, and peace of mind. Foremost literature reveals that while financial literacy required more special education to improve insurance literacy, the literature of consumers' insurance literacy is quite low. Defining and appropriately measuring insurance literacy is essential to understand the educational impact as well as barriers to better utilization of insurance products. Thus, we conducted a systematic literature review using PRISMA guidelines and analyzed 37 studies focusing on the construct validation criteria. This study developed a conceptual definition with an approach for a measurement instrument to address the current limitations in establishing a standardized measure of consumers' insurance literacy. We identified six knowledge dimensions and skill dimensions to be incorporated into an instrument developed to measure the insurance literacy construct. The study contributes to both insurance and financial literacy, and provide a foundation for further research into consumers' insurance literacy.
\end{abstract}

Keywords: Consumers' Insurance Literacy, Insurance literacy measure, Insurance Knowledge, insurance education, Financial Literacy, Insurance

DOI: $10.7176 / \mathrm{EJBM} / 11-26-05$

Publication date:September $30^{\text {th }} 2019$

\section{Introduction}

Financial reform of different countries evidence that regulators have increasingly shifted responsibility for financial decision making to consumers, while the range and complexity of financial products have increased(OECD, 2016). Financial literacy has attracted the attention of government, academia, and the industry as it is increasingly perceived as playing a vital role in consumers' financial decision-making about retirement saving, investment, borrowing and the management of debt and insurance (ASIC, 2011). A more recent study revealed that financial literacy does not necessarily translate to insurance literacy, and more specialized education can improve insurance literacy (Lin et al., 2018a); which is supported the findings of Huston (2010), financial literacy and financial education found that only 16 of the 52 studies ( 30.8 percent) considered insurance and risk management topics. According to Tennyson (2011), consumers' insurance literacy is relatively low and significantly vary with demographic characteristics. Hence, there is a need for a more consistent conceptual definition for insurance literacy and instrument to measure the literacy. The ideal instrument should have include core dimensions to address core insurance issues, So that result could be compared and an adequate educational decision taken. The process leading towards insurance literacy is called insurance education and the ultimate goal of insurance literacy is to accomplish behavioral changes, reflected in higher acceptance and better utilization of insurance products to achieve consumers' financial well-being.

Insurance products and services make up a significant fraction of the national economy and are essential in household budgeting and financial planning (Tennyson, 2011, ASIC, 2014, OECD, 2008, ANZ, 2015). OECD insurance statistics 2016 (OECD, 2017) shows that the average insurance spending of those countries is $8.96 \%$ of GDP. The higher level of average household spending on insurance product evidence that insurance purchasing decision is one of the leading financial decision taken by many families. The insurance is among the most complex financial products that many consumers purchase in their lifetime (Tennyson, 2011, Tania Driver, 2018, Nesleha and Urbanovsky, 2016, McCormack et al., 2009). Insurance is a mechanism by which an individual or organization can exchange its uncertainty for greater certainty. Insurance is purchased to protect against risks ${ }^{1}$ to life, health, property, liability, and loss of income. The nature of these risks and products to ensure them is differ considerably. Therefore, an informed purchasing decision is required for people to select an appropriate level of coverage, to understand policy terms \& contractual features, to compare services and financial soundness of competitive insurers, and to understand their rights and responsibilities under the contracts.

To assess the current level of insurance literacy and explore means to improve it, need to develop a construct which measures consumer's ability to make effective insurance decision. Despite its importance, only a few academic studies have given attention to how insurance literacy is measured (Tennyson, 2011, Tania Driver, 2018,

\footnotetext{
${ }^{1}$ Risk - risk refers to an uncertainty about an outcome; there are different classifications of risk, among others only pure risks can be insured, where loss is the only possible outcome. For example; life - illness, death or bodily injury; Property - loss and / or damage; Liability - liability of the insured for an injury caused to the person or property of other etc.
} 
McCormack et al., 2009, GIZ, 2017, CoreData, 2014, Lin et al., 2018a). The terms insurance literacy, insurance knowledge, and insurance education often are used interchangeably in the literature and popular media. Few scholars have attempted to define or differentiate these terms. Other than health insurance literacy, currently, there are no commonly accepted standardized instruments to measure consumers' insurance literacy. Prior studies on insurance literacy highlighted the necessity of having research focused primarily on the measurement of consumers' insurance literacy (Tennyson, 2011, Tania Driver, 2018, Lin et al., 2018a, Uddin, 2017). According to Lin et al. (2018a), there are limited studies on how financial literacy translates to understanding insurance-specific concepts and definitions of insurance literacy are not as prominent in the literature.

The purpose of this paper is to explore and analyze the existing literature on insurance literacy and identify obstacles and propose a conceptual definition as well as an approach to develop a more standardized measure of consumers' insurance literacy. Considering the limitation of existing literature on insurance-specific and its relationship with finance, the researcher looked to the financial literacy literature as a starting point to develop a conceptual formwork for measuring a construct termed 'consumers insurance literacy.' It is crucial having a commonly accepted standard construct for comparison studies and meta-analyses. According to the best of the author's knowledge, this is the first attempt to identify and organize research related to insurance literacy systematically and comprehensively and an effort to introduce a standard scale to measure insurance literacy. Health insurance literacy is a unique area of financial literacy, and the existing literature has given much attention to it. Therefore, this article contributes to both insurance and financial literacy and provide a foundation for further research into consumers' insurance literacy.

Rest of the article is structured as the data-search methods and process employed for analysis of the articles, review of the results, obstacles to a standard insurance literacy measure, proposed conceptual definition and approach to a measurement instrument of consumers' insurance literacy, discussion and conclusions with the limitation of the study and an outline for further research

\section{Methodology}

The literature review conducted following the structure proposed by the PRISMA statement as a guideline for undertaking systematic reviews (Moher et al., 2009). Academics have used this method to increase literature reviews' quality by eliminating the bias associated with the selection of articles to provide the best possible evidence in support of clinical and policy decisions (Cook et al., 1997, Parris and Peachey, 2013). The search for articles was done in three iterations. The first iteration was performed using the keywords included in the identification phase (see Figure 01). Secondly, in the screening phase, duplicates were removed, and finally, in the eligibility phase, articles filtered for the final analysis.

\subsection{Literature search and identification}

As shown in Figure 01, first, articles were identified by means of the electronic databases: Elsevier, Web of Science, EBSCO Academic Search Premier, JSTOR, Sagepub, Science Direct, the Taylor \& Francis Online Journal Library, and Wiley Online library were used because they contain largest digital libraries for journals and conference proceeding that publish research combining educational, engineering, technical aspect and social science. Further, an additional systematic search using Google Scholar was conducted to ensure maximum feasibility coverage of the review. The search was conducted with the keywords 'insurance literacy', 'financial literacy AND insurance,' 'Financial AND Insurance Education,' 'Insurance knowledge.' To identify the most relevant studies, the author limited the keyword search to the article title; article keywords; and the abstract. Further, no date range or additional exclusion criteria were applied for the literature search and expected to capture all published articles of human capital related to consumers' insurance literacy measures. Through cross-references, additional sources were added to this list. Secondly, identified articles categorized by the databases they appeared in; then, identified, and eliminated the duplication arising from references found in multiple databases. The initial search generated 64 potential articles. 


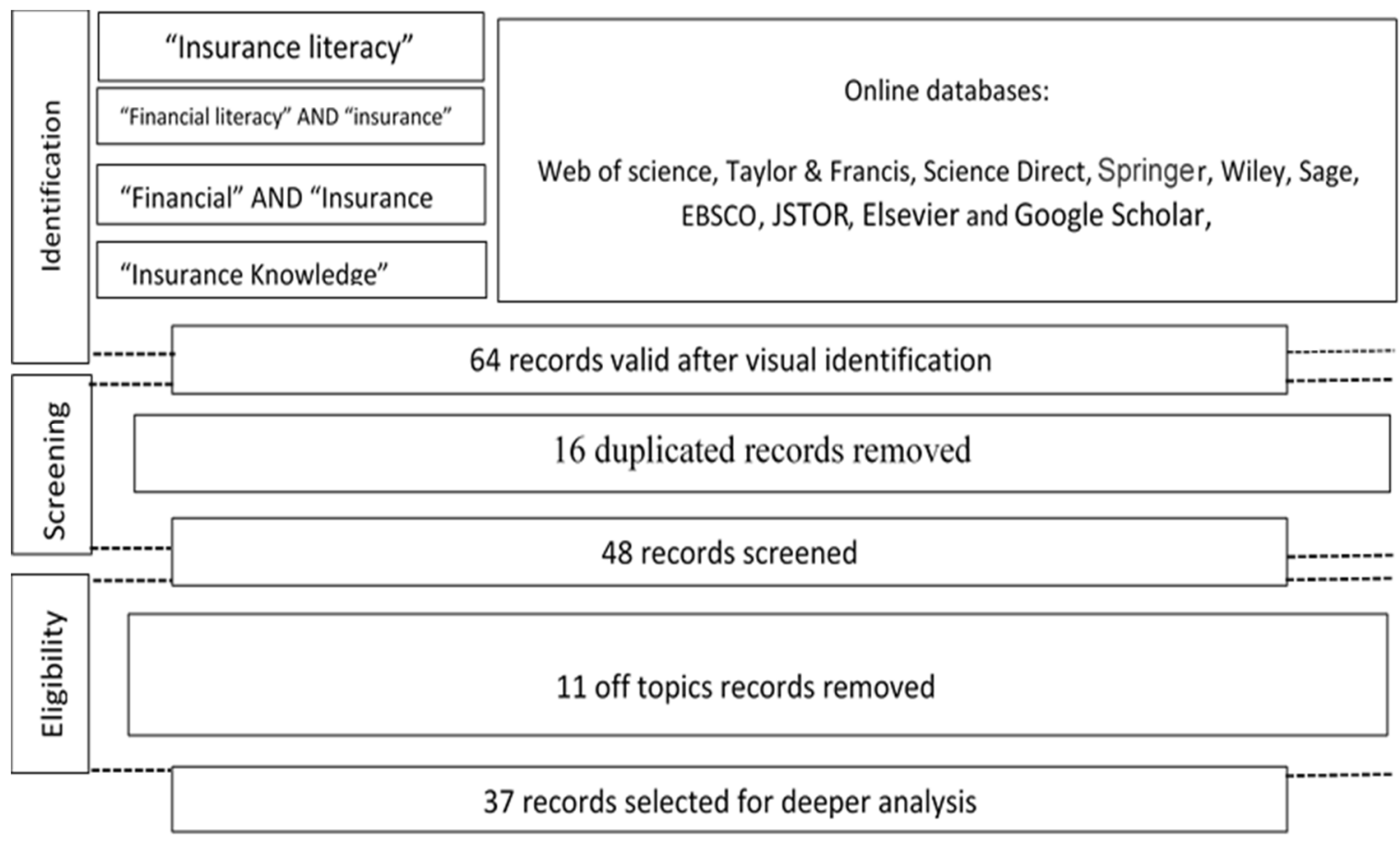

Figure 01: Research Methodology according to the PRISMA framework

\subsection{Method of Analysis}

Since the purpose of this review is to establish elements of consumers' insurance literacy measure, the previous studies were analyzed emphasizing information related to validation of construct. The construct validity is the heart of any study in which researchers use a measure as an index of a variable that is not itself directly observable (Westen and Rosenthal, 2003). According to Pedhazur (1991), the logical analysis approach to construct validation involves four main phases; they are a definition of the construct, item content, measurement procedures, and scoring procedures. Probably the most important, certainly the first, aspect of logical analysis is to study the definition of the construct. The definition allows for operationalization by providing a complete and mutually exclusive construct from other constructs. Second, the item content determines the instrument content and often involves setting items from each relevant domain as indicators of the given construct. Third, the measurement procedures mean general methods of measurement such as how data were collected (interview, rating scales); specific features of such methods (directions to respondents, item order, item wording); and conditions of administration. Fourth, the scoring procedures are essential in rating, communicating, and providing consistency in testing and interpreting results from an instrument. It can also affect the validity of inferences made based on them.

The previous literature records selected for more in-depth analysis were assessed based on mainly the logical analysis approach. Accordingly, each study coded based on; first, whether the construct was defined, at least theoretically discussed in addition to operational measure or a definition could be implied. Secondly, the item content was coded based on types of insurance and dimensions of knowledge components. After examining the commonality, mainly three types of insurance emerged: life insurance, property and casualty insurance, and health insurance. The dimension of knowledge content was also coded to identify the missing part of the prior conceptual definitions and empirical studies.

The measurement procedure was addressed by examining the number of instrument items and the method of data collection used. The number of items specifically included measuring the insurance knowledge, or insurance literacy was coded. Instruments scrutinized to identify the issues of the scoring procedure and recorded how the criteria were used to determine if an individual is insurance literate. The sample size and the target audience also were coded. 
Table - 1: Summary of Information

Table 1 summarized the information of selected 37 studies under the instrument evaluation criteria of construct, content, structure, rating and target population.

\begin{tabular}{|c|c|c|c|c|c|c|c|c|c|c|}
\hline \multicolumn{2}{|c|}{$\begin{array}{l}\text { Data / Study } \\
\text { Information }\end{array}$} & \multicolumn{2}{|c|}{ Construct } & \multicolumn{2}{|c|}{ Content } & \multicolumn{3}{|c|}{ Structure } & \multicolumn{2}{|c|}{ Other } \\
\hline $\begin{array}{c}\text { Ser } \\
1\end{array}$ & References & $\begin{array}{l}\text { Definition } \\
\text { Included } \\
2\end{array}$ & $\mathbf{I K}=\mathrm{IL}^{3}$ & $\begin{array}{l}\text { Knowledge } \\
\text { Content }^{4}\end{array}$ & $\begin{array}{c}\text { Types of } \\
\text { Insurance } \\
5\end{array}$ & $\underset{6}{I \text { Items }}$ & Data Coll ${ }^{7}$. & $\underset{8}{\text { Rating }}$ & $\begin{array}{c}\text { Target } \\
\text { Audience } \\
9\end{array}$ & $\begin{array}{c}\text { Sample } \\
\text { Size(N) } \\
{ }_{10}\end{array}$ \\
\hline 01 & $\begin{array}{l}\text { Tennyson } \\
\text { (2011) }\end{array}$ & Yes & Yes & CON, IP & $\begin{array}{c}\text { LIF, P\&C, } \\
\text { HEL }\end{array}$ & 10 & SUV, P & YES(ii) & GAP & 362 \\
\hline 02 & $\begin{array}{l}\text { Urbanovsky } \\
\text { and Nesleha } \\
(2017)\end{array}$ & No & Yes & $\begin{array}{l}\text { CON, IP, } \\
\text { RD }\end{array}$ & $\mathrm{BFC}, \mathrm{LIF}$ & NR & SUV, P & $\mathrm{NO}$ & IPH & NR \\
\hline 03 & $\begin{array}{ll}\text { Tania } & \text { Driver } \\
(2018) & \\
\end{array}$ & No & Yes & $\mathrm{CON}, \mathrm{IP}$ & LIF & $\begin{array}{l}06, \\
\mathrm{QM}\end{array}$ & INT, PB & YES(ii) & $1 \mathrm{G}, \mathrm{PIF}$ & 70 \\
\hline 04 & $\begin{array}{l}\text { CoreData } \\
(2014)\end{array}$ & SW & Yes & $\mathrm{CON}, \mathrm{IP}$ & LIF & NR & SUV, WEB & YES(i) & $\begin{array}{l}\text { GAP,AD, } \\
\text { GAP ,UA }\end{array}$ & 814 \\
\hline 05 & $\begin{array}{l}\text { Lin et al. } \\
(2018 a)\end{array}$ & Yes & No & $\begin{array}{l}\text { RE, CON, } \\
\text { IP }\end{array}$ & $\mathrm{BFC}$ & 08 & SUV, PE & YES(ii) & PST(UA) & 120 \\
\hline 06 & Uddin (2017) & OR & Yes & CON, IP & $\begin{array}{l}\text { LIF, P\&C, } \\
\text { HEL }\end{array}$ & 10 & SUV, PE & YES & GAP ,UA & 356 \\
\hline 07 & $\begin{array}{l}\text { McCormack et } \\
\text { al. }(2009)\end{array}$ & OR & Yes & CON, IP & HEL & 17 & INT,PE & YES(ii) & GAP ,UA & 1,202 \\
\hline 08 & $\begin{array}{l}\text { Tilley et al. } \\
(2018)\end{array}$ & No & Yes & $\begin{array}{l}\text { CON, IP, } \\
\text { RD, IS }\end{array}$ & HEL & NR & INT,PE & $\mathrm{NO}$ & PIF & 19 \\
\hline 09 & $\begin{array}{l}\text { Politi et al. } \\
(2016)\end{array}$ & No & No & $\mathrm{CON}, \mathrm{IP}$ & HEL & NR & SUV,WEB & $\mathrm{NO}$ & GAP ,UA & 343 \\
\hline 10 & $\begin{array}{l}\text { Paez et al. } \\
(2014 a)\end{array}$ & SW & No & $\begin{array}{c}\text { IP, IS, } \\
\text { CON, RMS }\end{array}$ & HEL & 42 & SUV, PE & $\mathrm{NO}$ & GAP ,UA & 828 \\
\hline 11 & $\begin{array}{l}\text { Mahdzan and } \\
\text { Victorian } \\
\text { (2013) }\end{array}$ & No & No & CON & LIF & NR & SUV,P & NO & GAP ,UA & 259 \\
\hline 12 & $\begin{array}{l}\text { Jacopo Bonan } \\
\text { et al. }(2011)\end{array}$ & No & Yes & $\begin{array}{c}\text { CON, IP, } \\
\text { RE }\end{array}$ & HEL & NR & INT,PE & NO & GAP,AD & 360 \\
\hline 13 & $\begin{array}{l}\text { Dalkilic and } \\
\text { Kirkbesoglu } \\
(2015)\end{array}$ & No & Yes & $\mathrm{CON}$ & $\mathrm{BFC}$ & NR & SUV,P & NO & STU(AD) & 400 \\
\hline 14 & $\begin{array}{l}\text { GIZ (2017), } \\
\text { (Cude, 2018) }\end{array}$ & OR & Yes & $\begin{array}{l}\text { RE, RMS, } \\
\text { CON, IP, } \\
\text { RD }\end{array}$ & $\begin{array}{l}\text { LIF, P\&C, } \\
\text { HEL }\end{array}$ & NR & 1B, SUV, P & NO & $\begin{array}{l}\text { GAP(AD), } \\
\text { GAP (UA) }\end{array}$ & NR \\
\hline 15 & $\begin{array}{l}\text { Bristow } \\
(2001)\end{array}$ & OR & Yes & CON, IP & $\begin{array}{l}\text { BFC, LIF, } \\
\text { P\&C, } \\
\text { HEL }\end{array}$ & 10 & SUV, PE & YES(ii) & GAP ,UA & 368 \\
\hline 16 & $\begin{array}{l}\text { (NAIC) } \\
(2010)\end{array}$ & No & Yes & $\mathrm{CON}, \mathrm{IP}$ & $\begin{array}{c}\text { BFC, LIF, } \\
\text { P\&C, } \\
\text { HEL }\end{array}$ & 10 & SUV, PE & YES(ii) & GAP ,UA & 1,011 \\
\hline 17 & ANZ (2008) & OR & Yes & $\begin{array}{l}\text { CON, IP, } \\
\text { RD }\end{array}$ & $\begin{array}{l}\text { BFC, LIF, } \\
\text { P\&C, } \\
\text { HEL }\end{array}$ & NR & INT, TEL & NO & $\begin{array}{l}\text { GAP(AD), } \\
\text { GAP (UA) }\end{array}$ & 3,500 \\
\hline 18 & ANZ (2011) & OR & Yes & $\begin{array}{l}\text { CON, IP, } \\
\text { RD }\end{array}$ & $\begin{array}{l}\text { BFC, LIF, } \\
\text { P\&C, } \\
\text { HEL }\end{array}$ & NR & INT, TEL & NO & $\begin{array}{l}\text { GAP(AD), } \\
\text { GAP (UA) }\end{array}$ & 3,502 \\
\hline
\end{tabular}

\footnotetext{
${ }^{1}$ Ser $=$ Reviewed Study Number

${ }^{2}$ YES=Definition Included, NO=Definition Not Included, SW=Somewhat defined, DIM=Definition Implied

${ }^{3}$ IK=Insurance Knowledge, IL= Insurance Literacy, YES=Insurance Knowledge equal insurance literacy, NO= Not equal IK to IL

${ }^{4} \mathbf{R E}=$ Risk exposure, $\mathbf{R M S}=$ Risk mitigation strategy, $\mathbf{C O N}=$ Concept / principles / terminology \& benefit of Insurance, $\mathbf{I P}=$ Insurance product,

$\mathbf{R D}=$ Rights \& duties of insured, IS=Information sources

${ }^{5} \mathbf{B F C}=$ Basic financial concepts \& numerical skills, $\mathbf{L I F}=$ Life Insurance, $\mathbf{P} \& \mathbf{C}=$ Property \& Casualty Insurance, $\mathbf{H E L}=\mathrm{Health}$ Insurance

${ }^{6} \mathrm{NR}=$ Not reported, $\mathrm{GM}=$ Qualitative Measures

${ }^{7}$ INT=Interview, $\mathbf{S U V}=$ Survey, TEL=Telephone, $\mathbf{P E}=$ In-person, $\mathbf{P}=$ Paper based, $\mathbf{W E B}=$ Web-based, $\mathbf{F N}=$ Format not specified

${ }^{8}$ YES=Rating system used, NO=Rating System not used, YES(i)= Ordinal ranking system, YES(ii)= A percentage of Item Answered

${ }^{9} \mathbf{G A P}=$ General Adults Population, $\mathbf{S T}=$ Students, PST $=$ Postgraduate Stu., $\mathbf{P I F}=$ professionals in the field, IPH=Insurance Policy Holders, $\mathbf{A D}=$ Advised, $\mathbf{U A}=$ Unadvised,

${ }^{10} \mathbf{N R}=$ Not Reported
} 


\begin{tabular}{|c|c|c|c|c|c|c|c|c|c|c|}
\hline$\underset{1}{\text { Ser }}$ & References & $\begin{array}{l}\text { Definition } \\
\text { Included } \\
2\end{array}$ & $\mathrm{IK}=\mathrm{IL}^{3}$ & $\begin{array}{l}\text { Knowledge } \\
\text { Content }\end{array}$ & $\begin{array}{c}\text { Types of } \\
\text { Insurance } \\
5\end{array}$ & $\underset{6}{\operatorname{Items}}$ & $\begin{array}{c}\text { Data } \\
\text { Coll } \\
7 .\end{array}$ & $\underset{8}{\text { Rating }}$ & $\begin{array}{c}\text { Target } \\
\text { Audience }^{9}\end{array}$ & $\begin{array}{c}\text { Sample } \\
\text { Size(N) } \\
10\end{array}$ \\
\hline 19 & ANZ (2015) & OR & Yes & $\begin{array}{c}\text { CON, IP, } \\
\text { RD }\end{array}$ & $\begin{array}{l}\text { BFC, LIF, } \\
\text { P\&C, } \\
\text { HEL }\end{array}$ & NR & $\begin{array}{l}\text { INT, } \\
\text { TEL }\end{array}$ & $\mathrm{NO}$ & $\begin{array}{l}\text { GAP(AD), } \\
\text { GAP (UA) }\end{array}$ & 3,400 \\
\hline 20 & $\begin{array}{l}\text { Beal and } \\
\text { Delpachitra }(2010)\end{array}$ & No & Yes & $\mathrm{CON}, \mathrm{IP}$ & $\begin{array}{l}\text { BFC, } \\
\text { P\&C }\end{array}$ & 05 & SUV,P & $\mathrm{NO}$ & $\mathrm{ST}(\mathrm{AD})$ & 837 \\
\hline 21 & Moore (2003) & No & No & $\mathrm{CON}$ & $\mathrm{BFC}$ & 02 & $\begin{array}{l}\text { INT, } \\
\text { TEL }\end{array}$ & $\mathrm{NO}$ & GAP,UA & 1,423 \\
\hline 22 & $\begin{array}{l}\text { Chen and Volpe } \\
(1998)\end{array}$ & No & No & $\mathrm{CON}, \mathrm{IP}$ & $\begin{array}{l}\text { BFC, } \\
\text { P\&C, } \\
\text { HEL }\end{array}$ & 06 & $\begin{array}{l}\text { SUV, } \\
\text { PE }\end{array}$ & $\mathrm{NO}$ & $\mathrm{ST}(\mathrm{AD})$ & 924 \\
\hline 23 & Mandell (2008) & No & No & $\mathrm{CON}, \mathrm{IP}$ & $\begin{array}{l}\mathrm{BFC}, \\
\mathrm{P} \& \mathrm{C}\end{array}$ & NR & $\begin{array}{l}\text { SUV, } \\
\text { PE }\end{array}$ & $\mathrm{NO}$ & ST(AD) & 6,856 \\
\hline 24 & $\begin{array}{l}\text { Chen and Volpe } \\
(2002)\end{array}$ & No & No & $\mathrm{CON}, \mathrm{IP}$ & $\begin{array}{l}\text { BFC, } \\
\text { P\&C }\end{array}$ & NR & $\begin{array}{l}\text { SUV, } \\
\text { PE }\end{array}$ & $\mathrm{NO}$ & $\mathrm{ST}(\mathrm{AD})$ & 924 \\
\hline 25 & Cude et al. (2013) & No & Yes & $\mathrm{CON}, \mathrm{IP}$ & $\begin{array}{l}\text { BFC, LIF, } \\
\text { P\&C }\end{array}$ & 03 & $\begin{array}{c}\text { SUV, } \\
\text { PE }\end{array}$ & $\mathrm{NO}$ & $\mathrm{ST}(\mathrm{AD})$ & 722 \\
\hline 26 & Desai (2015) & No & Yes & CON, IP & $\begin{array}{l}\text { BFC, LIF, } \\
\text { P\&C }\end{array}$ & NR & $\begin{array}{c}\text { SUV, } \\
\text { PE }\end{array}$ & $\mathrm{NO}$ & GAP & NR \\
\hline 27 & NCAER (2011) & No & Yes & $\begin{array}{l}\text { RE,RMS, } \\
\text { CON, IP, } \\
\text { RD, IS } \\
\end{array}$ & $\begin{array}{c}\text { BFC, LIF, } \\
\text { P\&C, } \\
\text { HEL } \\
\end{array}$ & NR & SUV,P & $\mathrm{NO}$ & GAP & 14,560 \\
\hline 28 & $\begin{array}{l}\text { Wells and Stafford } \\
\text { (1997) }\end{array}$ & No & Yes & IP, RD & $\begin{array}{l}\text { BFC, } \\
\text { P\&C }\end{array}$ & NR & SUV,P & $\mathrm{NO}$ & IPH & 623 \\
\hline 29 & $\begin{array}{l}\text { Brenda Wells et al. } \\
\text { (2015) }\end{array}$ & No & Yes & $\mathrm{CON}, \mathrm{IP}$ & $\mathrm{P} \& \mathrm{C}$ & NR & SUV,P & $\mathrm{NO}$ & $\begin{array}{c}\text { ST(AD), } \\
\text { ST(UA) }\end{array}$ & 311 \\
\hline 30 & $\begin{array}{l}\text { Reza Ofoghi and } \\
\text { HajipourFarsangi } \\
(2013)\end{array}$ & No & Yes & CON, IP & $\begin{array}{l}\mathrm{BFC} \\
\mathrm{P} \& \mathrm{C}\end{array}$ & NR & $\begin{array}{l}\text { SUV, } \\
\text { PE }\end{array}$ & $\mathrm{NO}$ & GAP & 497 \\
\hline 31 & Ramteke (2014) & No & Yes & IP & LIF & NR & $\begin{array}{l}\text { SUV, } \\
\text { PE }\end{array}$ & $\mathrm{NO}$ & GAP & 34 \\
\hline 32 & Bonan et al. (2017) & No & Yes & CON, IP & HEL & NR & SUV,P & $\mathrm{NO}$ & $\begin{array}{l}\text { GAP(AD), } \\
\text { GAP (UA) }\end{array}$ & 360 \\
\hline 33 & $\begin{array}{l}\text { Kawinski and } \\
\text { Majewski (2017) }\end{array}$ & No & Yes & $\mathrm{CON}$ & $\mathrm{BFC}$ & NR & SUV,P & $\mathrm{NO}$ & GAP ,UA & NR \\
\hline 34 & $\begin{array}{lll}\text { Dillingh et } & \text { al. } \\
(2015) & & \\
\end{array}$ & No & yes & IP & $\begin{array}{l}\text { BFC, } \\
\text { HEL }\end{array}$ & NR & FN & $\mathrm{NO}$ & GAP & NR \\
\hline 35 & $\begin{array}{l}\text { Ackah and Owusu } \\
(2012)\end{array}$ & No & Yes & $\mathrm{CON}, \mathrm{IP}$ & $\mathrm{BFC}, \mathrm{LIF}$ & 06 & SUV,P & YES(ii) & GAP & 303 \\
\hline 36 & Tennyson (2002) & No & No & $\mathrm{CON}, \mathrm{RD}$ & $\mathrm{BFC}$ & NR & $\begin{array}{l}\text { INT, } \\
\text { TEL }\end{array}$ & $\mathrm{NO}$ & GAP & 602 \\
\hline 37 & $\begin{array}{ll}\text { Olapade } & \text { and } \\
\text { Frolich (2012) }\end{array}$ & No & Yes & $\mathrm{CON}, \mathrm{IP}$ & $\mathrm{BFC}, \mathrm{LIF}$ & 11 & SUV,P & YES & GAP & NR \\
\hline
\end{tabular}

\footnotetext{
${ }^{1}$ Ser $=$ Reviewed Study Number

${ }^{2}$ YES=Definition Included, NO=Definition Not Included, SW=Somewhat defined, DIM=Definition Implied

${ }^{3}$ IK=Insurance Knowledge, $\mathbf{I L}=$ Insurance Literacy, YES=Insurance Knowledge equal insurance literacy, $\mathbf{N O}=\mathrm{Not}$ equal IK to IL

${ }^{4} \mathbf{R E}=$ Risk exposure, $\mathbf{R M S}=$ Risk mitigation strategy, $\mathbf{C O N}=$ Concept / principles / terminology \& benefit of Insurance, $\mathbf{I P}=\mathrm{Insurance}$ product,

$\mathbf{R D}=$ Rights \& duties of insured, IS=Information sources

${ }^{5} \mathbf{B F C}=$ Basic financial concepts \& numerical skills, $\mathbf{L I F}=$ Life Insurance, $\mathbf{P} \& \mathbf{C}=$ Property \& Casualty Insurance, $\mathbf{H E L}=$ Health Insurance

${ }^{6} \mathbf{N R}=$ Not reported, GM=Qualitative Measures

${ }^{7}$ INT=Interview, SUV=Survey, TEL=Telephone, $\mathbf{P E}=$ In-person, $\mathbf{P}=$ Paper based, $\mathbf{W E B}=$ Web-based, $\mathbf{F N}=$ Format not specified

${ }^{8}$ YES $=$ Rating system used, NO=Rating System not used, YES(i) $=$ Ordinal ranking system, YES(ii) $=$ A percentage of Item Answered

${ }^{9} \mathbf{G A P}=$ General Adults Population, $\mathbf{S T}=$ Students, PST=Postgraduate Stu., $\mathbf{P I F}=$ professionals in the field, IPH=Insurance Policy Holders, $\mathbf{A D}=$ Advised, $\mathbf{U A}=$ Unadvised

${ }^{10} \mathbf{N R}=$ Not Reported
} 
Table 2 - Summary of the Measurers Used in the Reviewed Studies (37)

\begin{tabular}{|c|c|}
\hline Category & Frequency / \% \\
\hline $\begin{array}{l}\text { Construct } \\
\text { Definition included } \\
\text { Yes } \\
\text { No } \\
\text { Discussed somewhat } \\
\text { Implied }\end{array}$ & $\begin{array}{lc}02 & 5.4 \% \\
26 & 70.3 \% \\
02 & 5.4 \% \\
07 & 18.9 \%\end{array}$ \\
\hline $\begin{array}{l}\text { Knowledge = literacy? (Mixed constructs) } \\
\text { Yes } \\
\text { No } \\
\text { Both }\end{array}$ & $\begin{array}{lc}28 & 75.7 \% \\
09 & 24.3 \% \\
10 & 27 \%\end{array}$ \\
\hline $\begin{array}{l}\text { Knowledge Content } \\
\text { Risk exposure } \\
\text { Risk mitigation strategy } \\
\text { Concept / principles / terminology \& benefit of Insurance } \\
\text { Insurance product } \\
\text { Rights \& responsibilities of insured } \\
\text { Information sources }\end{array}$ & $\begin{array}{lr}03 & 8.1 \% \\
02 & 5.4 \% \\
33 & 89.2 \% \\
32 & 86.5 \% \\
09 & 24.3 \% \\
04 & 10.8 \%\end{array}$ \\
\hline $\begin{array}{l}\text { Types of Insurance } \\
\text { Basic Financial Concepts / Numerical skills } \\
\text { Life Insurance } \\
\text { Property and Casualty insurance } \\
\text { Health Insurance }\end{array}$ & $\begin{array}{ll}22 & 59.4 \% \\
18 & 48.6 \% \\
18 & 48.6 \% \\
17 & 45.9 \%\end{array}$ \\
\hline $\begin{array}{l}\text { Structure } \\
\text { Number of items }(\mathrm{N}=14,23 \text { not reported }) \\
\text { Mean } \\
\text { Mode } \\
\text { Minimum } \\
\text { Maximum }\end{array}$ & $\begin{array}{l}10 \\
10 \\
02 \\
42\end{array}$ \\
\hline $\begin{array}{l}\text { Data Collection } \\
\text { Interview } \\
\text { Survey } \\
\text { Interview Telephone } \\
\text { Interview in person } \\
\text { Survey - in person } \\
\text { Survey - Paper } \\
\text { Not reported }\end{array}$ & $\begin{array}{l}27.0 \% \\
67.6 \% \\
13.5 \%(27 \%) \\
13.5 \%(27 \%) \\
35.1 \%(67.6 \%) \\
32.4 \%(67.6 \%) \\
2.7 \%\end{array}$ \\
\hline $\begin{array}{l}\text { Rating } \\
\text { Provided } \\
\text { Not provided } \\
\text { Ordinal rank imposed } \\
\text { Percentage of Item Answered }\end{array}$ & $\begin{array}{l}27 \% \\
73 \% \\
2.7 \%(27 \%) \\
24.3 \%(27 \%)\end{array}$ \\
\hline $\begin{array}{l}\text { Target Group } \\
\text { General Adults Population } \\
\text { Undergraduate Students } \\
\text { Postgraduate Students. } \\
\text { Professionals in the insurance field } \\
\text { Insureds } \\
\text { Advised Gen Public / postgraduate stud. / Students } \\
\text { Unadvised Gen Public / postgraduate stud / Students }\end{array}$ & $\begin{array}{l}64.8 \% \\
16.2 \% \\
2.7 \% \\
5.4 \% \\
5.4 \% \\
21.6 \%(64.8 \%) \\
59.4 \%\end{array}$ \\
\hline
\end{tabular}

\subsubsection{Construct}

The review evidenced that majority of previous studies $(70.3 \%)$ were not included a definition of construct insurance literacy, and only 5.4\% included some discussion about the elements of insurance literacy in addition to the specific measures of those studies. Five percent $(5.4 \%)$ of the studies provided a formal definition for the 
construct operationalized while some of them attempted to focus only on knowledge component. For example, CoreData (2014) defined insurance literacy in such a way that measures the consumer's knowledge regarding life insurance products. The definitions used by Tennyson (2011) and Lin et al. (2018a) were included both knowledge and confidence of decision making of the consumers. Comparatively much successful operational definition developed by Lin et al. (2018a) and attempted to include perceived risk exposure as well to the knowledge and skills required to make a sound insurance decision.

The majority of the studies $(75.7 \%)$ reviewed, used the term insurance knowledge instead of insurance literacy and twenty-seven percent $(27 \%)$ included both terms interchangeably (Table 02). If two constructs are conceptually different, then using the terms interchangeably indicate a potential problem.

\subsubsection{Content}

Review of the literature revealed that six knowledge content areas under the three types of insurance were used in different degrees. The knowledge and understanding of different risk mitigation strategies; principles/concepts/ terminologies \& benefits of Insurance; different Insurance products; rights \& responsibilities of insured; and information sources to make sound insurance decision on perceived risk are the six content areas of insurance knowledge. Only NCAER (2011) focused on all the content areas of insurance knowledge. The majority of the studies $(86.4 \%)$ covered at least two content areas, such as product knowledge and concepts \& benefits of insurance. As shown in table 01 , just over sixteen percent (16.2\%) were focused on one content area, with over $86.5 \%$ interested in items of insurance products. The measures that incorporate all content areas of insurance knowledge are likely to be more accurate.

The content areas that frequently used in previous studies were identified under three types of insurance (Table 1): life insurance ${ }^{1}$, Property \& Casualty Insurance ${ }^{2}$, and Health insurance ${ }^{3}$.

Twenty-four percent $(24.3 \%)$ of the studies analyzed were included three types of insurances as their measures. Approximately half of the measures (48.6\%) included health insurance and life insurance concepts, whereas forty-eight percent $(48.6 \%)$ included property and casualty insurance-related concepts and product measures. Fifty-six percent $(56.7 \%)$ of the measures were comprised of two or three types of insurance. Just over sixty-two percent (62.1\%) were focused solely on one type of insurance, together with measures of basic concepts. Since different types of insurance own unique concepts and product features from each other, measures with all types of insurance are likely to be more precise in the assessment of consumers' insurance literacy.

\subsubsection{Structure}

Table 2 shows the significant variation of the number of items used in the studies to measure the insurance literacy construct, (minimum $=02$, maximum $=42$ ). The majority $(62.1 \%$ ) of the studies analyzed did not mention the number of items used to measure the human capital related to insurance literacy.

In terms of data collection, sixty-seven percent $(67.6 \%)$ of the studies used survey method while twenty-seven percent $(27 \%)$ relied on interview technique. The internet-based online data collection method used by five percent $(5.4 \%)$.

\subsubsection{Rating}

Over one fourth $(27 \%)$ of the studies reviewed, reported an indicator of whether a respondent was insurance literate or not. The remaining studies did not provide criteria or a grading system to interpret the result from the measure. Out of the studies that provided a scale to interpret the measure, $2.5 \%$ used the ordinal ranking system. For example, CoreData (2014) provided a literacy score range from 1-10 and interpreted as; 7-10 > excellent insurance literacy, 5-6 > fair insurance literacy and 1-4> poor insurance literacy. Another study, Tennyson (2011) used a score range from a low of $0(0 \%)$ to a high $10(100 \%)$ and the identified average score on the quiz as $58 \%$ percent, however, no interpretation key was given.

\subsubsection{Other}

As shown in Table 2, the majority of studies targeted at general consumers as their audience (60\%). The most common target group out of the general public were the students (undergraduate and postgraduate students). Among the studies reviewed, 21.6 percent has been used advised consumers ${ }^{4}$ for their studies. Further, the sample size of the studies ranged from 19 to 14,560 .

\section{Challenges to a standardized insurance literacy measure}

The literature review revealed that while there are some common themes among published works, the majority of the existing research lacks consistency with regards to conceptualization and definition of the construct insurance

\footnotetext{
${ }^{1}$ Life insurance - life insurance covers risks associated with human mortality and morbidity

${ }^{2}$ Property and casualty insurance $(\mathrm{P} \& \mathrm{C})$ - P\&C insurance is focused on risks that result in loss and / or damage to property and possessions. For example; Auto insurance, Home insurance, commercial insurance, marine insurance, Professional liability insurance.

${ }^{3}$ Health insurance - covers the whole or a part of the risk of a person incurring medical expenses. The coverage that provides for the payments of benefits as a result of sickness or injury.

${ }^{4}$ Advised consumers - A professional financial planners, Insurance Agents, Insurance Brokers or any other educators can empower consumers to make informed and confident decision in insurance. The peoples who received such advices is called 'advised consumers'.
} 
literacy, a content of the instrument and interpretation of the instrument. The conceptualization and definition are the most important for the development of a standardized approach to measure and compare insurance literacy. The analysis evidence that only (02) studies used insurance literacy as the measurement construct and definitions they used were varying with elements (insurance knowledge, insurance education). This is an obstacle since all the stages of the instrument development depend on having a complete and well-defined construct. Further, existing studies did not reveal the use of a comprehensive measure of consumers' insurance literacy with frequently using types of insurance ${ }^{1}$. The final obstacle to developing a standardized approach to measuring insurance literacy is lack of a guide to the interpretation of measurement. Out of the reviewed studies, the majority (73\%) did not include a guide for the interpretation of measurement instrument and missing of this explanation is a barrier to the general understanding of insurance literacy construct. Further, the current research also lacks consensus on what might be a desirable level of literacy for the average consumers.

\section{A new approach to measure insurance literacy.}

Insurance literacy is a complex construct that encompasses a certain level of knowledge and a range of skills required for consumers to use and navigate the insurance system effectively. The proposed approach developed using the concepts, methods and empirical evidence of consumer knowledge and financial decisions; Also the new approach addresses the shortcomings of the existing instruments and attempts to capture key elements of the insurance literacy comprehensively.

\subsection{Insurance Literacy as a Construct: Concept and Definition}

It is often the case that when dealing with human concepts such as knowledge, difficulties lies not only in measurement but also in the definition of the construct. Existing literature identified financial knowledge as an essential component in analyzing the consumer decisions, yet, there is no commonly accepted standardized definition has been developed up to date. The different definitions and measures used in previous studies are reasonable in their assumptions and were expected to capture some aspect of financial knowledge, it is not clear as to whether or not the various measures are capturing the same construct. While there are some common themes among published works, the majority of the research available lacks consistency about how literacy is defined and how knowledge is measured (Huston, 2010, Remund, 2010, Adriana ZAIT, 2014, Lamdin, 2010)

Given that literacy as a concept has proved to be both complex and dynamic, continuing to be interpreted and defined in a multiplicity of ways. Traditionally, literacy refers to a person's ability to read and write. National Assessment of Adult Literacy (NAAL) of the United States defines literacy as both task-based and skill-based. The task-based (conceptual) definition "the ability to used printed and written information to function in the society, to achieve one's goals, and to develop one's knowledge and potential." The skills-based (operational) definition emphasis the skills required to perform the task-based. Many definitions of concept literacy exist in the academic world. Literacy in the broad sense consists of knowledge and skills required to understand and use materials related to a real context. This idea has been extended to include certain skill sets; for example statistical literacy (Callingham and Watson, 2005), computer literacy (Van Vliet et al., 1994), investment literacy (Volpe, 2002), health literacy (Nutbeam, 2008), financial literacy (Huston, 2010). Different types of literacy measure how well an individual can understand and use information. According to Huston (2010), financial literacy refers to the measurement of how well an individual can understand and use personal financial-related information. Similarly, health literacy refers to how well a person can understand and use health-related information. Fear (2008) expand literacy concept by incorporating 'ability to translate knowledge into action.' Accordingly, financial literacy defined an individual's knowledge, understanding, and the ability to translate knowledge into action. Fear (2008) emphasized that the translation process of knowledge into action (behavior) involves both cognitive and psychological dimensions. Such definition considers not only the understanding of financial concepts but also the importance of being able to apply knowledge to make a useful financial decision. The Australian Securities and Investment Commission (ASIC) defined financial literacy as "knowing how to make sound money decisions" and state that making a right financial decision is a core skill to a quality life and overall economic health of society (ASIC, 2014). A few scholars have claimed that knowledge is of less value without skills or ability. According to Remund (2010) financial literacy defined as "measure of the degree to which a person understands key financial concepts and has the necessary ability and confidence to manage own finances through the short-term decision and long-term planning, taking into consideration the economic events and changing conditions." This definition highlighted the importance of including measurement word to the definition as 'degree' or 'level'.

The literature revealed that the concept of financial literacy contains several aspects such as financial knowledge (Aren and Zengin, 2016, ASIC, 2014, Huston, 2010, Remund, 2010, Lin et al., 2017); ability to communicate about different financial concepts (Remund, 2010); skill to use different financial concepts and

\footnotetext{
${ }^{1}$ Frequently using types of insurance - in practice, there are different types of insurance products but all of them are not commonly used by average consumers, insurance policies such as life insurance, Auto insurance, Home insurance, health insurance, professional liability insurance are frequently used by average consumers.
} 
instruments (Huston, 2010, Remund, 2010, Hung et al., 2009); ability to take financial decisions (Remund, 2010, ANZ, 2015, Orton, 2007); attitude towards the use of financial instruments (Orton, 2007); confidence of financial performance (Huston, 2010, Remund, 2010, ASIC, 2014, Adriana ZAIT, 2014); financial behavior (Huston, 2010, Remund, 2010, Orton, 2007).

Similar to other kind of literacy (general literacy, financial literacy, health literacy), insurance literacy could be conceptualized as having dimensions of knowledge and understanding of personal risk exposure, risk handling method, operation of insurance mechanism, suitable insurance policy, rights and duties of insured and inquiry process; and use of such knowledge in decision making in insurance. Empirical studies revealed that consumers' knowledge and decision skills related to insurance purchases are lacking (Tania Driver, 2018, Uddin, 2017, Tennyson, 2011). The literature discovered that except health insurance, only a few studies had been attempted to conceptualize and define consumers' insurance literacy. Health insurance is a select type of insurance category which concentrates on one area of risk. According to Paez et al. (2014a), Health insurance is one of the most complex and costly products that consumers purchase and use in their lifetime. In some countries, peoples cannot afford or access to health care system without a health insurance cover. As the compulsory nature of health insurance, academics and researchers have attempted to conceptualized and measure the peoples' health insurance literacy. According to (Paez et al., 2014a), health insurance literacy is defined as "the degree to which individuals have the knowledge, ability, and confidence to find and evaluate information about health plans, select the best plan for their own (or family's) financial and health circumstances, and used the plan once enrolled."

A consumer survey conducted by Zurich Financial Service and Financial Planning Association of Australia defined the life insurance literacy concerning knowledge and understanding of the scope of cover provided in the life insurance policy (CoreData, 2014). This definition address only the knowledge dimensions and does not focus on the application of knowledge into decision making. A US field survey conducted by Tennyson (2011) assesses consumers' knowledge, confidence, and capability in insurance decision. This study assessed consumers' insurance knowledge and also asked respondents to self-report their confidence in insurance decision making. The study result concluded that insurance literacy most significantly correlates with financial education and interest in personal finance, whereas the confidence was related to insurance decision making and information source preferred by consumers. A more recent study conducted by Lin et al. (2018a) investigated whether higher financial literacy can be translated to better performance in making insurance decision. This study suggested a comparatively successful operational definition for the insurance literacy by which incorporated the understanding of individuals' perceived risk exposure also into consideration. According to Lin et al. (2018a), the insurance literacy defined as; "understanding the concept of insurance and being knowledgeable and informed about insurance products under consideration; having a reasonable understanding of the risks covered by the insurance policy under consideration; and being able to apply the knowledge and understanding to evaluate insurance options and make insurance decisions that are consistent with the perceived risks". However, this operational definition does not address the consumers understanding and confidence to find and evaluate basic personal risk mitigation strategies on perceived risk, and responsibility of the insured once purchased. For example, understanding of duties such as information disclosing requirement of the policyholder during the policy period and understanding of where to get more information and purchase suitable insurance. When developing the construct insurance literacy, attention should be given to include such necessary knowledge components to the measurement instrument.

\subsection{Recommended Conceptual Definition}

Mostly the conceptual definition explains abstract concepts in a concrete term. The previous literature evidences the need for a more consistent conceptual definition for insurance literacy.

The concept of Insurance literacy can be defined as a combination of knowledge, skills, attitude, and behavior necessary to make a sound insurance decision, based on potential risk exposure and individual circumstances, to improve peace of mind and financial wellbeing.

Therefore, insurance literacy measure the level of knowledge, skills and confidence of an individual to select insurance mechanism among other personal risk management strategy; decide appropriate insurance products with right cover to handle the potential risk; evaluate such cover with terms and conditions involved therein; understand rights and duties when using the insurance product, and awareness of necessary information sources, to make sound insurance decision.

The proposed conceptual definition of insurance literacy is direct, does not contradict existing definitions within the literature, and is consistent with other standardized literacy constructs.

\subsection{The conceptual framework for consumers' insurance literacy}

The framework that we develop is based on the above literature, conceptual definition, and a few additional key studies. Firstly, we acknowledge that consumers knowledge and confidence in insurance decision is comparatively low and very with different socioeconomic status (Tennyson, 2011). Second, we build on the causal pathways between insurance literacy and well-being described by Tania Driver (2018), who emphasized the role of insurance 
literacy variables in this pathway. Third, we accept that the understanding of the concept of insurance and the ability to apply knowledge of risk into insurance decisions is not automatically translated from general financial literacy, whereas additional education more specific to insurance may significantly enhance these aspects (Lin et al., 2018a). Based on our working knowledge and prior research, we integrate a range of other variables into the conceptual framework. (Figure 2). Using this framework, we adopted knowledge and skills-based approach to measure consumers insurance literacy and link it to the ultimate goal of insurance, i.e., peace of mind (well-being) 4.3.1. Knowledge dimensions of insurance literacy:

Knowledge is the most common component of many conceptual definitions of literacy. To effectively use the insurance mechanism for the betterment, one must first know something about insurance. Scholars validate the significance of knowledge by refereeing how knowledge can improve well-being and peace of mind (Tania Driver, 2018, Howard, 2009). In the measurement of financial literacy, only a few studies have focused on the measurement of knowledge of insurance and protection instruments. For example, according to Huston (2010), only 16 out of the 52 studies (30.8 percent) considered insurance and risk management topics. Because of the complexity, prior studies on financial literacy identified insurance as a particular category (Adriana ZAIT, 2014, Huston, 2010, Remund, 2010, Lin et al., 2018b). According to Lin et al. (2017), financial literacy does not necessarily translate to insurance literacy, and more specialized education can improve insurance literacy. Therefore, there is a need to develop a set of knowledge content to measure the construct insurance literacy. This identification improves progress and opens the ability to design meaningful and useful insurance education programs.

We have identified six content areas of insurance knowledge to be incorporated to provide a more accurate measure. 1). Understanding potential risk exposure, 2). Risk mitigation strategies, 3). Concept, principles, and benefits of insurance, 4). Insurance products and covers 5). Rights and duties of insured, and 6). Information sources

\section{i. Understanding of Potential risk exposure}

Generally, peoples in society exposed to different types of personal, property, liability, and precautionary risks that can affect their financial position and quality of life - wellbeing. The possibility of such exposures may be loss or damage to Property; and pain, suffering, ill-health, and premature death. As a result of such risk exposure, current and future income may fluctuate and affect the long-term spending plans. (Mahdzan, 2008, Lin et al., 2017, Nesleha and Urbanovsky, 2016). The rational peoples are interested in insurance and other protection instruments based on their perception of potential risk exposure to their lives and properties. Therefore, the measure of perceived risk exposure is important to identify the level of risk aversion of an individual in insurance literacy construct.

\section{ii. Understanding of Risk mitigation strategies}

When a risk occurs, most of the peoples are not aware of the range of available financial options that can be used to cope with emergencies. The corporate risk management literature suggests that individuals and households have three main alternatives to deal with potential risk exposures; firstly, reduce the risk, by reducing either likelihood (frequency) of an adverse event or the severity (financial impact) of any consequences, secondly, protection using insurance; and thirdly, provide additional liquidity through precautionary saving. The understanding of leading personal risk management strategies and its comparative benefit help to take efficient consumer decision to handle potential risk exposure and consumption of insurance service (Vaughan and Vaughan, 2008). The literature review revealed that only a few studies were attempted to measure consumers' knowledge and understanding of personal risk mitigation strategies with the insurance decision of consumers. A study conducted by Tania Driver (2018) using a sample of Australia consumers revealed that knowledge of risk mitigation strategies is generally low and cause to exacerbate the level of insurance literacy of consumers. Generally, knowingly or unknowingly peoples use insurance service, precautionary saving, or different risk control techniques to manage their potential risks as a substitute or complement tool to each other. This is supported by the findings of (Hofmann and Peter, 2016, Crainich and Peter, 2016, Mahdzan and Victorian, 2013, Somerville, 2004). Therefore, when developing the insurance literacy construct, understanding of the consumer's basic risk mitigation knowledge is essential, because it provides an understanding of the ground-level motivation to acquire insurance knowledge and use of it.

\section{iii. Understanding Insurance concept and benefits}

Generally, the average individual/household spent a significant percentage of his or her disposable income on insurance over a time (Murray and Schmit, 2018, Tennyson, 2011, Tania Driver, 2018, CoreData, 2014, Barseghyan et al., 2013, Lin et al., 2017), and one of the logical reason for studying insurance is to learn how it can be used in personal financial planning(Vaughan and Vaughan, 2008). Still, others study insurance as a part of the discipline of risk management, the managerial function that aims at preserving the operating effectiveness of the organization.

The insurance is a risk transferring mechanism whereby an individual or organization can transfer their uncertainty with specific cost (premium). In addition to eliminating risk at the level of an individual through 
transfer, the insurance mechanism reduces risk and uncertainty for society as a whole - the concept of Insurance based on probability theory and law of large numbers. The accuracy of the insurer's predictions is based on the law of large numbers. By combining a sufficiently large number of homogeneous exposure units, the insurer can make predictions for the group as a whole using the theory of probability.

According to Tania Driver (2018), consumers trust in the insurance system is low and severely affected by the usage of insurance solutions. The knowledge about insurance concept and benefits may help to build the trust of insurance and motivate them to competently use insurance products to manage their risk and achieve financial well-being.

\section{iv. Understanding the Type of insurance products and perils covered}

The literature review revealed that most of the prior studies on insurance literacy were focused on the measurement of consumer's knowledge about insurance products. In such studies, the measure of literacy was limited to the variables of product knowledge of selected types of insurance. Due to the complexity and unique features of different product categories, most of the empirical studies were limited to one or two types of insurance. For example, Lauren McCormack et al. (2009) and Paez et al. (2014a) focused only the health insurance measures, whereas Uddin (2017) and Chen and Volpe (2002) measure life insurance and property insurance-related items (Table 01).

Generally, we can identify three types of insurance product categories frequently used in the insurance industry to treat the broad range of risk to which individual, household, and organizations are exposed. They are Life insurance, Property and Liability insurance, and health insurance (Vaughan and Vaughan, 2008). Firstly, Life insurance is designed to protect against two distinct risks; they are premature death and superannuation. Life insurance, endowments, and annuities protect the individual and his or her dependents against the undesirable financial consequences of premature death and superannuation. Secondly, Health insurance is protected against loss by sickness or accidental bodily injury, where loss may be the loss of wage caused by the sickness or accident, or it may be expenses for doctor bills, hospital bills, medicine, or the expenses of long-term care. Thirdly, property, and liability insurance, these forms of insurance is designed to protect against losses resulting from loss and or damage to property and losses arising from legal liability. In practice, there is a large number of insurance covers available in the insurance industry to cater to the requirements of customers. All of such insurances are subject to general and special exclusions and policy conditions. Therefore, insurance products are complex and challenging to understand for general customers without prior knowledge or assistant from an adviser. The consumers' knowledge of insurance product is generally low and significantly change with demographic factors(Tennyson, 2011). According to Tania Driver (2018), the majority of people have poor knowledge of personal insurance with many not seeing the value and importance of those policies.

Further, the research studies on financial literacy also have suggested that consumer knowledge of basic financial principles and product is minimal (Mitchell, 2011b) and might be inadequate for people to make sound financial decisions. Low financial literacy does not necessarily imply that people will make a poor financial decision; people can seek financial advice and guidance from reliable information sources to make insurance decisions (Riccardo Calcagno and Monticone, 2015).

\section{v. Understanding the rights and duties of insured}

Insurance is a special financial product with different conditions by which policyholders must fulfill some obligatory requirements during the policy period. For example, discloser of material facts ${ }^{1}$, duty to satisfy the warranty requirements ${ }^{2}$, risk mitigation effort at the time of claim. According to Tania Driver (2018), people have a poor understanding of their obligations about accurate and truthful disclosure about insurance. This conclusion support with the findings of ANZ survey of Adults financial literacy in Australia, only 42 percent of the respondent were aware that they must disclose all relevant information to the insurance and fail to do so could be refused the claim (ANZ, 2015). The consumers' ability to understand such duties is vital for decision making and may cause to reduce the disputes during the policy period. Therefore, items to measure knowledge and understanding of insured rights and duties is vital to include in the instrument of insurance literacy construct.

\section{vi. Awareness of information sources of insurance}

Those with low insurance literacy and low confidence were more likely to seek informal sources of insurance information like friends and family (Tennyson, 2011, Brenda Wells et al., 2015, Reza Ofoghi and HajipourFarsangi, 2013). According to Lin et al. (2018a), Insurance literacy may not be easily attainable, even for those with high financial literacy, making it challenging for individuals to make rational insurance decisions by themselves. This

\footnotetext{
${ }^{1}$ Material facts - Person who is seeking or using any kind of insurance policy requires to disclose any and all information related to the risk being insured at the being and during the policy period. This information is known as 'material facts' and used by the underwriter to assess the level of risk associated with insuring a particular individual. The insurer determine the coverage and the premium (cost) based on the degree of risk (level of risk)

${ }^{2}$ Warranty requirement - A warranty is a condition which forms part of the contract, whereby insured agreed some particular thing shall or shall not be done, or some condition shall be fulfilled. A breach of warranty enables the insurer to avoid a claim in respect of the property insured or a part thereof any time after the breach, whether or not the breach has increased the risk or whether or not the breach has any connection with the cause of loss, or the spread or aggravation of loss.
} 
highlight the necessity of trust in the insurance system in which consumers may often have little choice other than to trust the advice and guidance of insurers, agents, brokers, financial advisers, and the regulators. A survey study conducted with Australian consumers revealed that those who received financial advised on life insurance are considerably more likely than those who never received advice on life insurance to be insurance literacy (CoreData, 2014). It is evident that a professional financial planner, insurance agent, insurance broker empowers their clients with the knowledge and equips them to make decisions about risk and insurance-related decisions confidently. Therefore, awareness of reliable information sources of insurance providers, products, sales channels are items to be incorporated in the measuring instrument of insurance literacy construct.

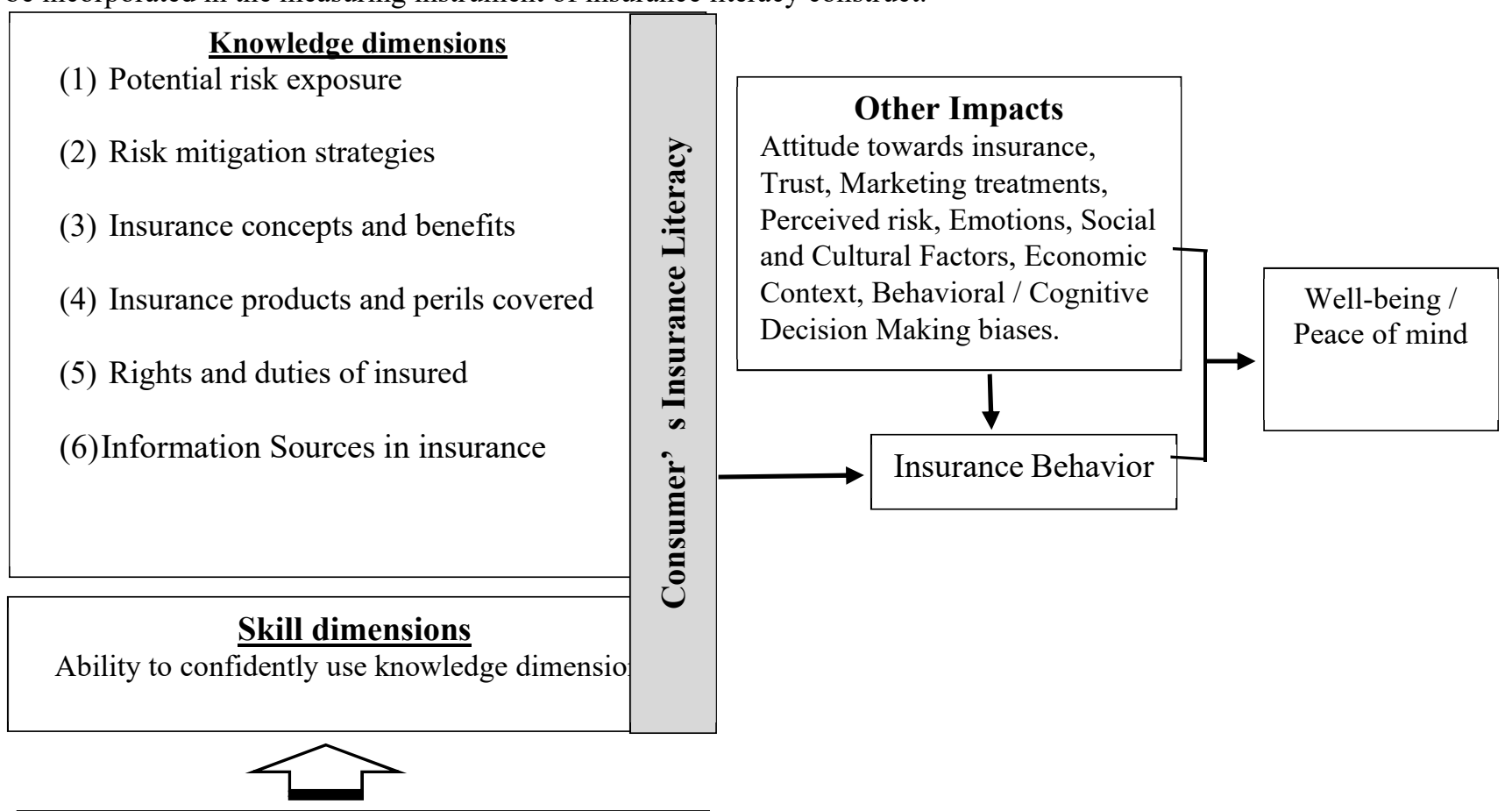

Insurance Education, Training, Advice and Experiences

Figure 02: Associations between insurance literacy, insurance education, behavior and well-being

Figure 2 shows the relationship between special insurance education, insurance literacy, behavior, and peace of mind (well-being). Insurance literacy consists of knowledge and application of human capital specific to insurance and personal risk management. The stock of financial knowledge and skills gained through education and experience influences a person's insurance literacy. For example, if an individual struggle with basic insurance and financial knowledge and skills like arithmetic, this will undoubtedly impact his/her insurance literacy. However, people can seek financial advice and guidance from reliable information sources to make insurance decisions (Riccardo Calcagno and Monticone, 2015). Therefore, information directly related to effectively navigating insurance decision is a more appropriate focus than basic financial knowledge and numerical skills for insurance literacy measure.

Insurance literacy is a component of human capital that can be used in risk handling decisions of personal and business activities to increase peace of mind and ultimately, well-being. High literacy or knowledge levels are not necessarily a guarantee that individuals will behave in the desired fashion, as insurance decisions are often influenced by other factors such as life experience, perceived risk, emotions, social and cultural factors, economic context, and behavioral/cognitive biases. Buying insurance is a rational decision, whereas literature evidence that consumers do not have a good feel for probabilities do not treat losses and gains symmetrically, and tend to overestimate emotionally-laden loss events while underestimating low-probability loss events. Therefore, it appears that when consumers obtain a deeper understanding of insurance solutions, they realize the value of it and make a more informed decision. Further, existing literature suggests that there is a relationship between knowledge or literacy and behavior in the market, though the exact nature of this relationship remains unclear (Mandell and Klein, 2009, Hilgert and Jeanne M. Hogarth, 2003, Lusardi and Mitchell, 2007, Robb and Sharpe, 2009). However, it seems that there is a need for a uniform measure before we can effectively study the relationship between literacy and behavior. The variety of measures used at present is confusing to draw definite conclusions and are issues relating to reliability and validity. These affect insurance education programmes as well.

Insurance education, training, advice, and experiences are the inputs to increase an individual's human capital 
specific to insurance knowledge and or application (i.e., insurance literacy). An individual's experience with insurance mechanism, including interaction with providers, influences insurance literacy, and along with their decision making, ultimately affect well-being. According to Huston (2010), a well-designed financial instrument with knowledge and application component provide insight into human capital needed to behave appropriately to enhance financial well-being. Therefore, a well-designed insurance literacy instrument that adequately captures a combination of knowledge, skills, attitude, and behavior necessary to make sound insurance decision can provide an understanding of how well insurance education, training, and advice improves the human capital needed to behave appropriately to enhance financial and subjective well-being.

\section{Operationalization of Insurance Literacy}

The Operationalization process transforms conceptual definitions into operational or measurable ones. In order to measure dimensions of insurance literacy, it is required to identify the most frequent types of insurance and products for which people need an insurance education. The literature review revealed that measures that frequently used in empirical studies could be broadly categorized into three types of insurance; namely life insurance, property and casualty insurance, and health insurance. Whereas, most of the prior studies are focused on special social categories such as high school students, elderly people, unemployed people, poor people, advised peoples, unadvised peoples (Table 1). All these different approaches on different segments of the population create a problem of comparing the result at an aggregate level, national level, or country level. Therefore, the ideal instrument should have core dimensions for core insurance issues, so that the result could be compared and the adequate educational decisions are taken.

In terms of content, it seems reasonable to use the three types of insurance content areas (life insurance, health insurance, property, and casualty insurance) that currently exist in the literature, with a focus on designing items strongly linked to the most common or more detrimental insurance mistakes.

If we accept the idea of three types of insurance - life insurance, property and casualty insurance, and health insurance with each dimension of insurance literacy (six knowledge dimensions and one skill dimension), we need questions or items for each type of insurance. Except for product knowledge dimension, all other knowledge and skill dimensions could be commonly measured without considering the types of insurance. To measure the knowledge dimension of insurance products, we need items for three types of insurance. Hence, a minimum of 9 questions or items would be necessary (five commonly measured knowledge dimension + three product knowledge specific dimension for types of insurance + one skill dimension). According to Huston (2010) and Kim et al. (1978), the minimum number of items necessary to measure a specific factor has to be between three and five. If we consider a minimum of three items for each dimension, then the measurement instrument would have at least twenty-seven $(9 \times 3)$ items without including questions for demographic information and general knowledge in finance. In assessing the levels of insurance literacy, consumers' general knowledge in financial terms assists in understanding the financial interest of the target group, and decision-making behavior with the level of insurance literacy. According to Mitchell (2011a), three multiple-choice questions related to interest, inflation, and diversification proposed to measure financial literacy. The measure has been broadly used by researchers worldwide, though at first it was proposed for a Health and Retirement Study in the United States. The instrument prepared in all these measures would be a long and rather difficult to apply instrument, but it would be the only possibility to get reliable and valid results, and thus comparable when the instrument is applied on different social groups of different countries. The literature review evidence that existing studies were focused on the measurement of one or two types of insurance to measure the consumers' insurance literacy. For example, life insurance (Tania Driver, 2018, CoreData, 2014), health insurance (McCormack et al., 2009, Paez et al., 2014b, Mathur et al., 2018, Kim et al., 2013), life, property and health insurance (Tennyson, 2011, Reza Ofoghi and HajipourFarsangi, 2013). Further, the number of questions used in previous studies to measure literacy is smaller than the one necessary for a reliable and valid measurement. After preparing the instrument, techniques such as item response theory approaches could be used to reduce the number of items (Maria Orlando Edelen et al., 2006) and the final instrument should be designed with the support of specialist in insurance, statistics and instrumental research , sociology and psychology to capture differences due to heterogeneous levels of economic, social and cultural development.

\section{Conclusion}

This paper aims at examining the existing literature of human capital related to insurance literacy and developing a conceptual definition with an approach for a measurement instrument to address the current limitation of insurance literacy construct. Thus, we conducted a systematic literature review that analyzed 37 studies under the construct validation criteria of construct, content, structure, rating, and target population. Literature reveals that financial literacy required more special education to improve insurance literacy, and the literature of consumers' insurance literacy is quite low. In this study, we introduce a conceptual definition for consumer insurance literacy as well as an approach to a measurement instrument. We identified six knowledge dimensions and skill dimensions 
to be incorporated into an instrument developed to measure the insurance literacy construct. Further, we developed a conceptual framework which explains the association between insurance literacy, insurance education, behavior, and well-being. The Insurance literacy measure only identifies the human capital required to engage in appropriate insurance behavior, and it does not ensure this will occur. Therefore, educators cannot assume that people with less than optimal insurance literacy are necessarily insurance illiterate.

Creation of financial education programmes designed specially to enhance insurance literacy has been viewed as a solution to mitigate problems, higher acceptance, and better utilization of insurance products to achieve the well-being of individual and families. Further, the literature on financial literacy evidence that not all financial education programmes are equally effective. Therefore, if the goal of insurance education is to increase insurance literacy, how do insurance educators know if they have succeeded without a standard insurance literacy measure? To recognize that an individual is insurance literate, he or she must demonstrate the knowledge and skills needed to make choices within the insurance market that all consumers face regardless of their characteristics. However, the reality is that insurance products are standards, and they are generally tailor-made to meet the individuals' requirements, no one-size-fits-all approach. Therefore, insurance education aimed at improving a person's level of knowledge and abilities should be tailored to suit different demographics, life stage, and learning styles.

A successful measure of insurance literacy will allow educators to identify education need and researchers to distinguish the impact of deficiency on behavior or well-being of consumers. Another necessary consequence of an instrument that effectively measures insurance literacy is that researchers are better able to identify what outcomes are mostly affected by a lack of insurance knowledge and skill. For example, insurance literacy is strongly associated with underinsurance ${ }^{1}$, then education efforts that improve literacy about these concepts among the consumers may lead to change their behavior and effect to financial well-being. Hence, there is a need to have a more consistent conceptual definition of insurance literacy and instrument to measure literacy. The ideal instrument should have core dimensions for core insurance issues so that the result could be compared and an adequate educational decision taken.

Although an insurance literacy measure may be used to predict insurance behavior, it does not necessarily imply that individuals will behave in a way that many scholars, policymakers, or educators would believe optimal. Other factors such as attitude, perceived risk, emotions, social and cultural factors, economic context, behavioral/cognitive decision-making biases or external circumstances also contribute to what may appear to be poor insurance decision making.

By its distinct nature, mistakes in insurance-decision will reveal at the time of insurance claim and can impact on indemnity of an individual as well as create negative externalities that affect all economic participants. Therefore, educators, policymakers, insurers, and researchers are interested in tracking variations and changes in insurance literacy rate. A standard approach to measure insurance literacy is needed to identify obstacles and solutions for actual insurance behavior.

Author Contributions: All the authors have contributed equally to the paper

Acknowledgments: Humanity and Social Science Research Project of Ministry of Education, PR China, "Identification and Approach and Evaluation System of Systematic importance of Financial Institutions."

Conflicts of Interest: The authors declare no conflict of interest."

\section{References}

(NAIC), O. N. A. O. I. C. 2010. New NAIC Insurance IQ Study Reveals Americans Lacking in Confidence, Knowledge of Insurance Choices. Press Release April 6.

ACKAH, C. \& OWUSU, A. 2012. Assessing the Knowledge of and Attitude towards Insurance in Ghana. Available:https://www.utwente.nl/igs/research/conferences/2012/microinsurance/Full\%20papers\%20and\%2 Opresentations/Full\%20papers\%202a/Ackah\%20\%26\%20Owusu_Microinsurance\%20paper_final.pdf.

ADRIANA ZAIT, P. E. B. 2014. Financial Literacy - Conceptual Definition and Proposed Approach for a measurement. Journal of Accounting and Mangement 4, 37-42.

ANZ 2008. ANZ Survey of Adult Financial Literacy in Australia. Australia.

ANZ 2011. Adult Financial Literacy in Australia Full Report of the results from the 2011 ANZ Survey. Australia.

ANZ 2015. ANZ Survey of Adult Financial Literacy in Australia Full Report of the Results from the 2014 ANZ survey. Melbourne: The Social Research Centre.

AREN, S. \& ZENGIN, A. N. 2016. Influence of Financial Literacy and Risk Perception on Choice of Investment. Procedia - Social and Behavioral Sciences, 235, 656-663.

ASIC 2011. National Financial Literacy Strategy. Report 229. Australian Securities and Investments Commission. ASIC 2014. National Financial Literacy Strategy 2014-17. Australian Securities and Investments Commission.

\footnotetext{
${ }^{1}$ Underinsurance - this refers to inadequate insurance coverage held by a policyholder. In the event of a claim, underinsurance may result in economic losses to the policyholder, since the damage would exceed the maximum amount that can be recovered by the insurance policy.
} 
BARSEGHYAN, L., MOLINARI, F., O'DONOGHUE, T. \& TEITELBAUM, J. C. 2013. The Nature of Risk Preferences: Evidence from Insurance Choices. American Economic Review, 103, 2499-2529.

BEAL, D. J. \& DELPACHITRA, S. B. 2010. Financial Literacy Among Australian University Students Economic Papers, 22, 65-78.

BONAN, J., DAGNELIE, O., LEMAY-BOUCHER, P. \& TENIKUE, M. 2017. The Impact of Insurance Literacy and Marketing Treatments on the Demand for Health Microinsurance in Senegal: A Randomised Evaluation. Journal of African Economies, 26, 169-191.

BRENDA WELLS, EPERMANIS, K. \& GIBSON, J. P. 2015. The Effect of Insurance Education on Consumer Attitudes: A Study of the Property and Casualty Industry. Journal of Financial Education 41, 47-65.

BRISTOW, B. J., AND S. TENNYSON 2001. Insurance Choices: Knowledge, Confidence and Competence of New York Consumers. Final Report. Cornell University.

CALLINGHAM, R. \& WATSON, J. M. 2005. Measuring statistical literacy. Journal of applied measurement, 6, 19-47.

CHEN, H. \& VOLPE, R. P. 1998. An Analysis of Personal Financial Literacy Among College Students. Financial Services Review, 7, 107-128.

CHEN, H. \& VOLPE, R. P. 2002. Gender Differences in Financial Literacy Among College Students Financial Services Review, 11, 289-307.

COOK, D. J., MULROW, C. D. \& HAYNES, R. B. 1997. Systematic reviews: synthesis of best evidence for clinical decisions. Ann Intern Med, 126, 376-80.

COREDATA 2014. The Life Insurance Literacy Gap (Zurich Financial Services Australia and Financial Planning Association of Australia. Sydney.

CRAINICH, D. \& PETER, R. 2016. Saving and the Demand for Protection Against Risk. Working Paper.

CUDE, B. J. 2018. Promoting Insurance Literacy. National Council of Insurance Legislators (NCIL) Conference. NCIL.

CUDE, B. J., KUNOVSKAYA, I., KABACI, M. J. \& HENRY, T. 2013. Assessing Changes in the Financial Knowledge of College Seniors. American Council on Consumer Interests, 59.

DALKILIC, N. \& KIRKBESOGLU, E. 2015. The Role of Financial Literacy on the Development of Insurance Awareness. International Journal of Economics and Finance, 7.

DESAI, S. K. 2015. Insurance Awareness : Necessary Pre-Condition for Further Growth of Insurance Industry of India. The Journal of Insurance Institute of India.

DILlingH, R., KOOREMAN, P. \& POTTERS, J. 2015. Probability Numeracy and Health Insurance Purchase. De Economist, 164, 19-39.

FEAR, J. 2008. Choice Overload : Australian Coping with Financial Decisions. Discussion Paper Number 99. The Australia Institute.

GIZ 2017. Insurance Literacy Efforts of the German Development Cooperation. In: PETERLECHNER, L. (ed.) Voices from the fiel. Bonn and Eschborn, Germany.

HILGERT, M. A. \& JEANNE M. HOGARTH 2003. Household Financial Management: The Connection between Knowledge and Behavior. Federal Reserve Bulletin

HOFMANN, A. \& PETER, R. 2016. Self-Insurance, Self-Protection, and Saving: On Consumption Smoothing and Risk Management. Journal of Risk and Insurance, 83, 719-734.

HOWARD, D. 2009. Insurance literacy in the United States. World Hosp Health Serv, 45, 4-6.

HUNG, A. A., PARKER, A. M. \& YOONG, J. 2009. Defining and Measuring Financial Literacy Working Paper 708. RAND Corporation.

HUSTON, S. J. 2010. Measuring Financial Literacy. Journal of Consumer Affairs, 44, 296-316.

JACOPO BONAN, OLIVIER DAGNELIE, PHILIPPE LEMAY-BOUCHER \& TENIKUE, M. 2011. Is it all about Money? A Randomized Evaluation of the Impact of Insurance Literacy and Marketing Treatments on the Demand for Health Microinsurance in Senegal. Research Paper No. 14. Microinsurance Innovation Facility. Geneva: ILO).

KAWINSKI, M. \& MAJEWSKI, P. 2017. Financial Literacy and Insurance Literacy in Poland Working Papers No. 3/2017 (232).

KIM, JAE-ON \& MUELLER, C. W. 1978. Factor Analysis: Statistical Methods and Practical Issues, Newbury Park SAGE Publications, Inc. .

KIM, J., BRAUN, B. \& WILLIAMS, A. D. 2013. Understanding Health Insurance Literacy: A Literature Review. Family and Consumer Sciences Research Journal, 42, 3-13.

LAMDIN, D. J. 2010. Consumer Knowledge and Financial Decisions: Lifespan Perspectives, International Series on Consumer Science, . In: XIAO, J. J. (ed.) International Series on Consumer Science. London: Springer.

LAUREN MCCORMACK, CARLA BANN, JENNIFER UHRIG, NANCY BERKMAN \& RUDD, R. 2009. Health Insurance Literacy of Older Adults. The Journal of Consumer Affairs, 43, 223-248.

LIN, C. N., HSIAO, Y. J. \& YEH, C. Y. 2017. Financial literacy, financial advisors, and information sources on 
demand for life insurance. Pacific-Basin Finance Journal, 43, 218-237.

LIN, X., BRUHN, A. \& WILLIAM, J. 2018a. Extending financial literacy to insurance literacy: a survey approach. Accounting \& Finance, 58.

LIN, X., BRUHN, A. \& WILLIAM, J. 2018b. Extending financial literacy to insurance literacy: a survey approach. Accounting \& Finance.

LUSARDI, A. \& MITCHELL, O. S. 2007. Baby Boomer retirement security: The roles of planning, financial literacy, and housing wealth. Journal of Monetary Economics, 54, 205-224.

MAHDZAN, N. S. \& VICTORIAN, S. M. P. 2013. The Determinants of Life Insurance Demand: A Focus on Saving Motives and Financial Literacy. Asian Social Science, 9.

MAHDZAN, S. D. A. N. S. A. 2008. Protection Insurance and Financial Well-being. A Report for the Financial Services Research Forum. Nottingham: University of Nottingham.

MANDELL (ed.) 2008. Financial Literacy of High School Students, New York, NY: Springer.

MANDELL, L. \& KLEIN, L. S. 2009. The Impact of Financial Literacy Education on Subsequent Financial Behavior. Journal of Financial Counseling and Planning, 20, 15-24.

MARIA ORLANDO EDELEN, DAVID THISSEN, JEANNE A. TERESI, AND, M. K. \& OCEPEK-WELIKSON, K. 2006. Identification of Differential Item Functioning Using Item Response Theory and the LikelihoodBased Model Comparison Approach: Application to the Mini-Mental State. Medical Care, 44, S134-S142.

MATHUR, T., DAS, G. \& GUPTA, H. 2018. Examining the influence of health insurance literacy and perception on the people preference to purchase private voluntary health insurance. Health Serv Manage Res, 951484818760529.

MCCORMACK, L., BANN, C., UHRIG, J., BERKMAN, N. \& RUDD, R. 2009. Health Insurance Literacy of Older Adults. Journal of Consumer Affairs, 43, 223-248.

MITCHELL, A. L. A. O. S. 2011a. Financial Literacy and Planning: Implications for Retirement Wellbeing. NBER Working Paper No. 17078. National Bureau of Economic Research

MITCHELL, A. L. A. O. S. 2011b. Financial Literacy around the World: An Overview. Pension Economic Finance, 10, 497-508.

MOHER, D., LIBERATI, A., TETZLAFF, J. \& ALTMAN, D. G. 2009. Preferred reporting items for systematic reviews and meta-analyses: the PRISMA statement. BMJ, 339.

MOORE, D. 2003. Survey of Financial Literacy in Washington State: Knowledge, behavior, Attitudes, and Experiences. Technical Report 03-39. Washington State University, Pullman: Social and Economic Sciences Research Center.

MURRAY, C. T. \& SCHMIT, M. 2018. Estimating a Change from TRICARE to Commercial Insurance Plans. Mil Med.

NCAER 2011. Pre-launch Survey Report of Insurance Awareness Campaign. New Delhi, India: National Council of Applied Economic Research.

NESLEHA, J. \& URBANOVSKY, K. 2016. Study of Financial Literacy in the Field of Insurance Products. European Financial System 2016: Proceedings of the 13th International Scientific Conference, 490-495.

NUTBEAM, D. 2008. The evolving concept of health literacy. Soc Sci Med, 67, 2072-8.

OECD 2008. Improving Financial Education and Awareness on Insurance and Private Pensions.

OECD 2016. Global Insurance Market Trends

OECD 2017. OECD Insurance Statistics 2016

OLAPADE, M. \& FROLICH, M. 2012. The Impact of Insurance Literacy Education on Knowledge, Attitude and Behavior - A Randomized Controlled Trial.

ORTON, L. 2007. Financial Literacy: Lessons from International Experience. CPRN Research Report. Canadian Policy Research Networks Inc. (CPRN).

PAEZ, K. A., MAllery, C. J., NOEL, H., PUGlieSE, C., MCSORleY, V. E., LUCADO, J. L. \& GANACHARI, D. 2014a. Development of the Health Insurance Literacy Measure (HILM): Conceptualizing and Measuring Consumer Ability to Choose and Use Private Health Insurance. Journal of Health Communication, 19, 225-239.

PAEZ, K. A., MALlery, C. J., NOEL, H., PUGlieSE, C., MCSORley, V. E., LUCADO, J. L. \& GANACHARI, D. 2014b. Development of the Health Insurance Literacy Measure (HILM): conceptualizing and measuring consumer ability to choose and use private health insurance. J Health Commun, 19 Suppl 2, 225-39.

PARRIS, D. L. \& PEACHEY, J. W. 2013. A Systematic Literature Review of Servant Leadership Theory in Organizational Contexts. Journal of Business Ethics, 113, 377-393.

PEDHAZUR, E. J. A. L. P. S. 1991. Measurement, Design, and Analysis: An Integrated Approach. Hillsdale, NJ: Lawrence Erlbaum Associates, Inc.

POLITI, M. C., KAPHINGST, K. A., LIU, J. E., PERKINS, H., FURTADO, K., KREUTER, M. W., SHACHAM, E. \& MCBRIDE, T. 2016. A Randomized Trial Examining Three Strategies for Supporting Health Insurance 
Decisions among the Uninsured. Med Decis Making, 36, 911-22.

RAMTEKE, P. 2014. Financial Literacy with Special Reference to Insurance Research Horizons, 4, 188-194.

REMUND, D. L. 2010. Financial Literacy Explicated: The Case for a Clearer Definition in an Increasingly Complex Economy. The Journal of Consumer Affairs 44, 276-295.

REZA OFOGHI \& HAJIPOURFARSANGI, R. 2013. The Effect of Insurance Knowledge on the Insurance Demand: the case study of Auto Insurance. Technical Journal of Engineering and Applied Sciences, 23, 33563364.

RICCARDO CALCAGNO \& MONTICONE, C. 2015. Financial Literacy and the Demand for Financial Advice. Journal of Banking \& Finance, 2015, 363-380.

ROBB, C. A. \& SHARPE, D. L. 2009. Effect of Personal Financial Knowledge on College Students' Credit Card Behavior. Journal of Financial Counseling and Planning, 20, 25-43.

SOMERVILlE, R. A. 2004. Insurance, Consumption, and Saving: A Dynamic Analysis in Continuous Time. The American Economic Review, 94, 1130-1140.

TANIA DRIVER, M. B., BRETT FREUDENBERG AND KATHERINE HUNT 2018. Insurance Literacy in Australia : Not Knowing the Value of Personal Insurance Financial Planning Research Journal, 4, 53-75.

TENNYSON, S. 2002. Insurance Experience and Consumers' Attitudes Toward Insurance Fraud. Journal of Insurance Regulation, 21, 35-55.

TENNYSON, S. 2011. Consumers' insurance literacy : evidance from survey data Financial Services Review, 20, 165-179.

TILlEY, L., YARGER, J. \& BRINDIS, C. D. 2018. Young Adults Changing Insurance Status: Gaps in Health Insurance Literacy. J Community Health.

UDDIN, M. A. 2017. Microinsurance in India: Insurance literacy and demand. Business and Economic Horizons, $13,182-191$.

URBANOVSKY, K. \& NESLEHA, J. 2017. Financial Literacy Testing in the Area of Insurance Products. Proceedings of the 9th International Conference on Currency, Banking and International Finance, 271-276.

VAN VLIET, P. J. A., KLETKE, M. G. \& CHAKRABORTY, G. 1994. The measurement of computer literacy: a comparison of self-appraisal and objective tests. International Journal of Human-Computer Studies, 40, 835857.

VAUGHAN, E. J. \& VAUGHAN, T. M. 2008. Fundamentals of Risk and Insurance, United States of America, John Wiley \& Sons, Inc.

VOLPE, R. P., KOTEL, J. E. \& CHEN, H. 2002. A Survey Of Investment Literacy Among Online Investors. Financial Counseling and Planning, 13, 1-13.

WELLS, B. P. \& STAFFORD, M. R. 1997. Insurance Education Efforts and Insurance Service Quality. Journal of Insurance Regulation, 15.

WESTEN, D. \& ROSENTHAL, R. 2003. Quantifying construct validity: Two simple measures. Journal of Personality and Social Psychology, 84, 608-618. 